仮声带粘膜下に発生した喉頭神経線維腫例

\author{
本島ひとみ・清水 勝利・浅井 正嗣・渡辺 行雄
}

\title{
Neurofibroma of the Larynx; A Case Report
}

\author{
Hitomi Motoshima, Katsutoshi Shimizu, Masatsugu Asai and Yukio Watanabe \\ (Toyama Medical and Pharmaceutical University)
}

\begin{abstract}
Neurogenic tumors of the larynx are not common. We report a case of neurofibroma of the larynx.

A 52-year-old female consulted us complaining of hoarseness lasting for two years. Laryngoscopic examination, CT and MRI revealed a mass occupying the left false vocal cord. A tumor was removed through an external neck incision under general anesthesia. The resected tumor was yellowish white with elastic firm consistency. The histopathological diagnosis indicated neurofibroma. It was not clear from which nerve the tumor had originated. The patient had no other neurogenic tumors and has been well without recurrence since the surgery.
\end{abstract}

Key words : neurofibroma, larynx, neurogenic tumor

はじめに

喉頭領域には乳頭腫，血管腫など様々の良性腫瘍が発 生するが，神経原性腫瘍は比較的まれであるとされてい る. 今回我々は仮声帯を中心に発生した神経線維腫の 1 例を経験したので若干の文献的考察を加えて報告する.

\section{症例}

患者 : 52歳, 女性.

主訴：嗄声.

家族歴：特記すべきことなし。

既往歴：高血压.

現病歴：1991年より軽度の嗄声が認められていたが放 置していた。1993年 8 月感冒罹患後より嗄声が増悪した ため, 某病院耳鼻咽喉科を受診し, 左仮声帯・左披裂喉 頭蓋ヒダ・左披裂部の腫脹を指摘された。抗生剂の投与 を受けたが効果なく，同年10月12日当科紹介受診となっ た。

全身所見：色素沈着や皮膚腫瘤を認めない。

局所所見：喉頭ファイバースコープ検査では粘膜は正
常に保たれて和り, 左仮声帯から声帯にかけて表面の滑 らかな膨隆を認めた(図 1 )。左声带の可動性は良好であ ったが腫瘤による前方部分の突出のため, 発声時に声門

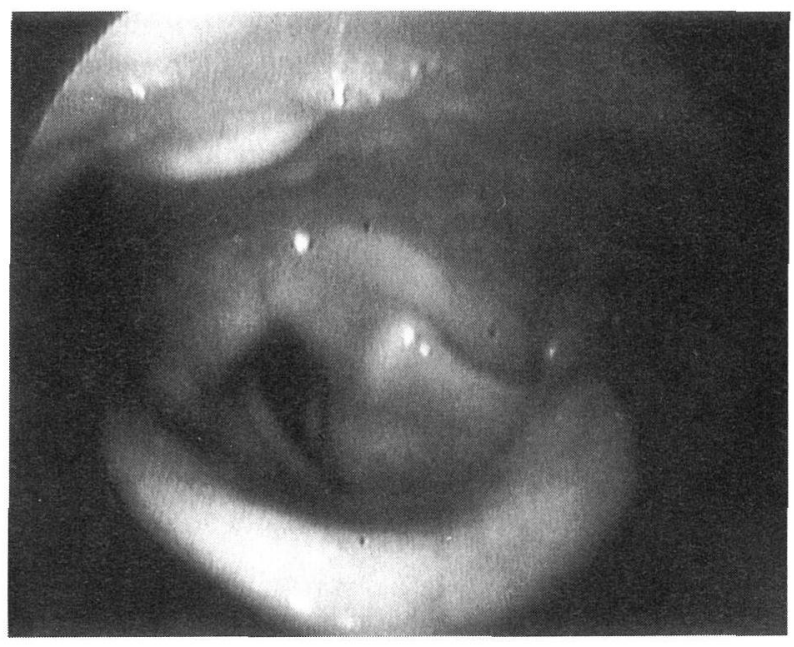

図 1 喉頭ファイバー所見 左仮声帯に表面平滑な膨隆が認められる. 
閉鎖不全を認めた。

CT 検査: 甲状軟骨, 左披裂軟骨扣よび左声帯に囲ま れた部位に低吸収の腫瘤陰影を認めた。境界は明瞭で周 囲への浸潤はなかった(図 2).

MRI 検查: T1 強調画像では軟部組織と同程度の中等 度信号強度, T2 強調画像では高信号強度の腫瘤影が, 左仮声带から声門下にかけて認められた(図 3-A, B). その他の耳鼻咽喉科領域に異常を認めず, 血液生化学検 查結果も正常範囲内であった. 以上の検查結果より, 仮 声帯粘膜下腫瘍を疑い, 12 月 8 日摘出手術を施行した.

手術所見：まず，術後の喉頭粘膜浮腫による呼吸困難 予防のため気管切開を施行した. 皮切は頸部左側より 字切開を加克, 甲状咽頭筋を切断・剥離して甲状軟骨後 縁を露出した。 その後, 輪状甲状関節を離断して甲状軟 骨を翻転し, 甲状軟骨裏面より，喉頭粘膜を損傷するこ となく腫瘍を摘出した。周囲組織への癒着・浸潤はなか った.

経過 : 術後, 反回神経麻痺は認められず, 嗄声も軽快 したため12月22日退院し, 現在外来にて経過観察中であ る。

標本：摘出した腫痬は大きさ $25 \times 13 \times 8 \mathrm{~mm}$ で黄白色,

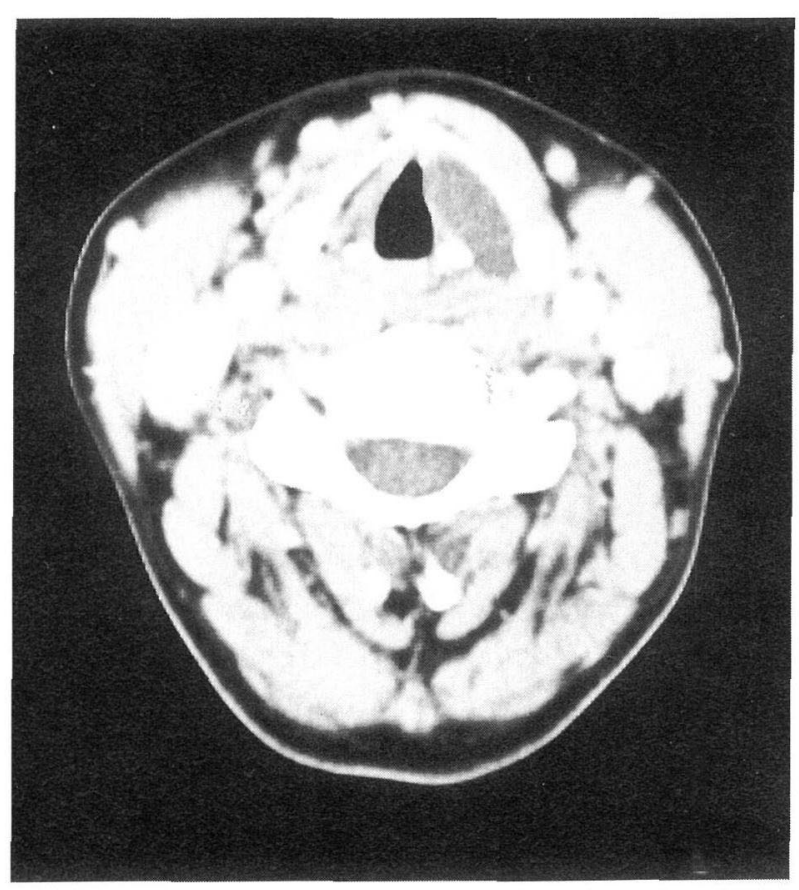

図 $2 \mathrm{CT}$ 像

境界明瞭な低吸収の腫癔陰影を認める。

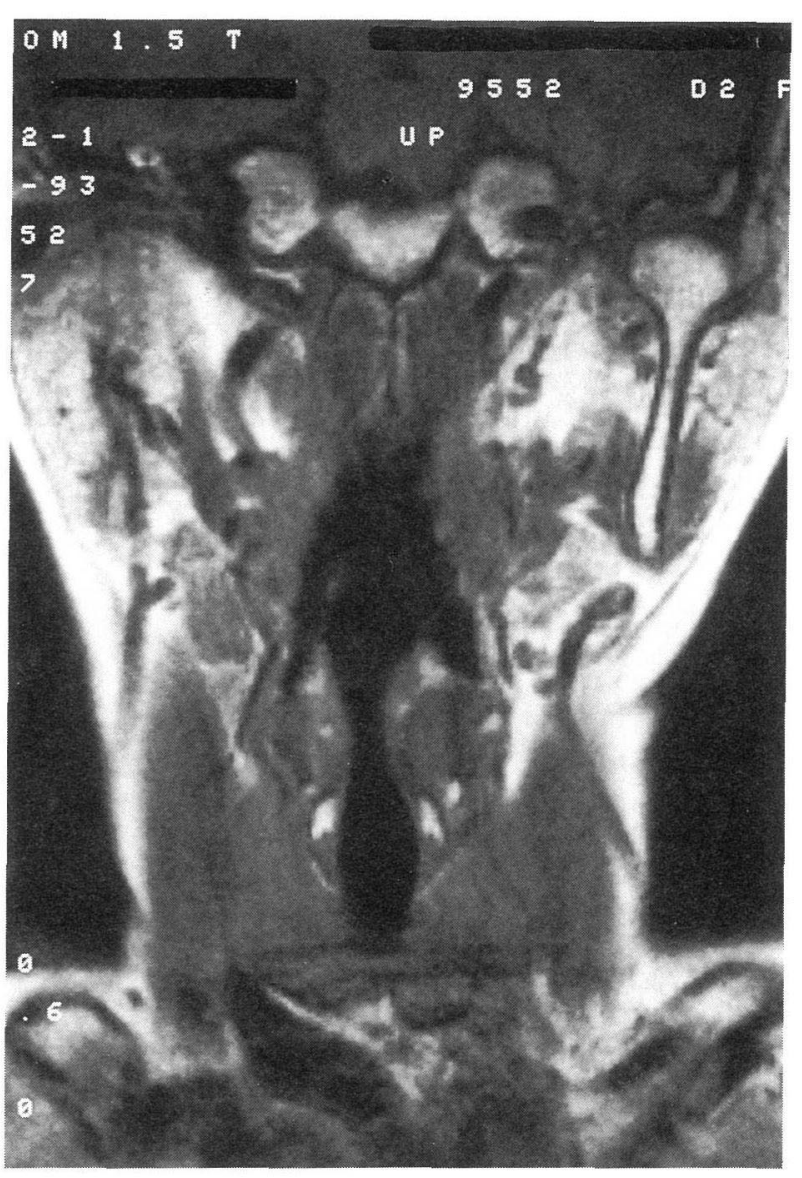

A

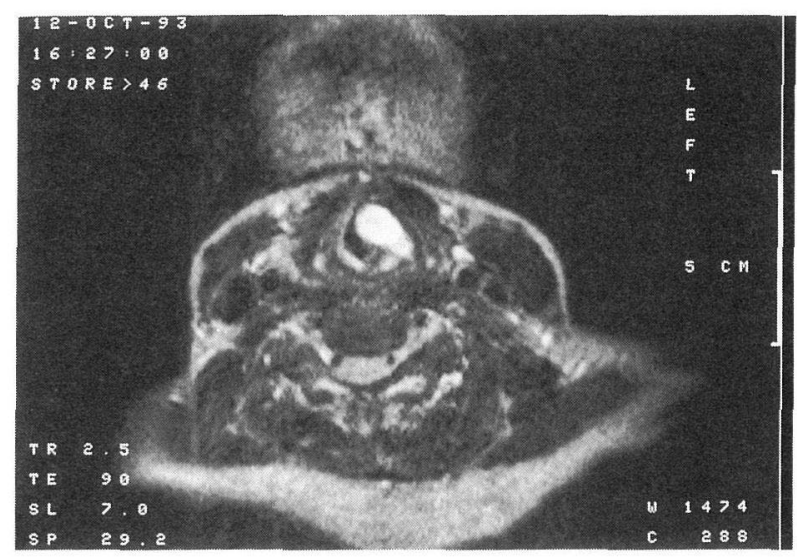

B

図 3 A MRI T1 強調画像 冠状断 B MRI T2 強調画像 軸位断

弾性硬で割面は充害性均一であった(図 4). 病理学所見 では腫瘍は不完全な薄い線維性被膜で覆われ, 先端が尖 


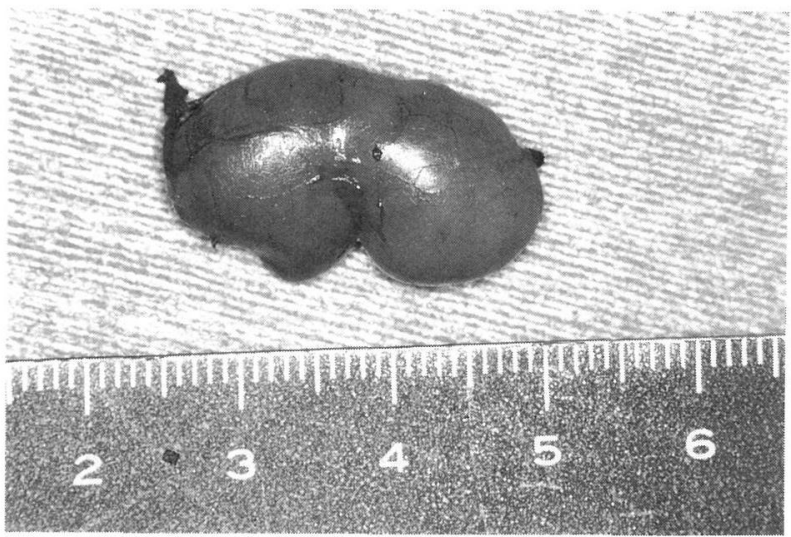

図 4 摘出物

つた核を持つ細胞と紡錘形の細胞の増殖よりなり間質は 粘液腫様で一部膠原線維性であり, 神経線維腫と診断さ れた(図 5 ).

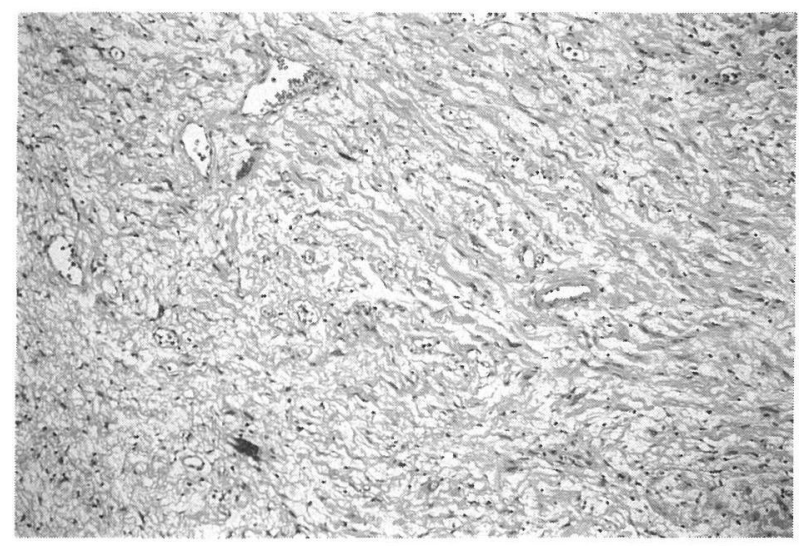

図 5 病理組織像 (HE 染色 100倍)

\section{考察}

神経原性腫瘍は耳鼻咽喉科領域においては聴神経腫瘍 が良く知られているが，喉頭に発生するものは比較的ま れである、末梢神経より発生する良性腫瘍は病理組織学 的に神経腫, 神経鞘腫, 神経線維腫に分類され, 発生頻 度は国外の文献によれば New ら 1) は喉頭の良性腫瘍722 例中神経線維腫は 1 例であったと報告し, Holinger ら 2$)$ は1197例中 1 例であったと報告している。本邦に括ける 喉頭の神経線維腫の報告は1965年中島ら 3 が最初の 1 例 を報告して扣り，以後現在まで我々が渉猟し得た範囲で
は自験例を含めて15例であった3) 16).

報告された神経線維腫15例をまとめると年齢別では 2 〜68歳まで幅広い分布を認め，平均34歳であったが好発 年齪は特になかった。性別では男性10名，女性 5 名之や や男性に多い傾向があった。症状は嗄声・呼吸困難・嚥 下困難など腫瘍の圧排によるもので，自発痛・嚥下時痛 は認められなかった。京た，神経の麻痺症状・刺激症状 はないとされている。発生部位では声帯・仮声帯が 6 例, 披裂部 4 例, 喉頭蓋 2 例, 喉頭蓋〜披裂喉頭蓋ヒダ 1 例, 披裂喉頭蓋ヒダ〜梨状陥凹 1 例, 声門下後壁が 1 例であ った。

発生起源となる神経は声門上部に好発することから上 喉頭神経内枝と考光られて括り, 同定し得た症例の報 告11) もあるが，一般に術中の同定は困難であり，本症 例でも発生神経を思わせる索状物は認められなかった。

他の良性腫瘍との鑑別は組織学的検査によらねばなら ないが，腫瘍が粘膜下に存在した場合，術前の生検は困 難であり摘出手術を施行して初めて確定診断が付くこと が多い.病理組織学的には辺縁部では粘液変性が主体で あり，組織成分が乏しいのに対して，中央部では細胞成 分が多い，午のため，単純 CT ではやや低吸収域を呈し， 造影 CT では中心部のみが増強される。屯た， MRI T1 強調像では全体的に中間信号, T2 強調では辺縁部が高 信号で，中央部は中間信号にとどまるとされている17). 本症例では腫瘍が小さく, 画像上内部はほぼ均一に描出 されていた。

治療は外科的切除であるが，部位・大きさにより経口 法と外頸部切開法が選択される8). 有茎性のものや腫瘍 が小さく限局しているものであれば経口法が可能である。 織田ら ${ }^{6)}$ は声帯膜様部に原発した神経線維腫の症例に対 し喉頭顕微鏡下レーザー手術を施行し, きわめて効果的 な治療であると述べている。本症例では腫瘍が仮声带粘 膜下に存在し, 画像上より得られた位置・大きさから判 断して経口法は困難であると考穴られたため, 外頸切開 法によった。

神経線維腫は孤立性発症の場合, レックリングハウゼ ン病との関係が少なく, 悪性化はまれとされている。本 症例では家族歴やカフェオレ斑, 全身の腫瘤などレック リングハウゼン病を疑わせる所見は認められなかったが， 喉頭に初発したレックリングハウゼン病の例18) も市り, 今後も十分な経過観察が必要であると考えた。 


$$
\text { まとめ }
$$

仮声帯粘膜下に発生した孤立性神経線維腫の 1 例を報 告した。併せて喉頭に発生した神経線維腫に関して文献 的考察を行った.

本論文の要旨は第22回日本耳鼻咽喉科学会富山県地方部会お よび第56回耳鼻咽喉科臨床学会にて発表した.

\section{参考文献}

1) New GB and Erich JB : Benign tumors of larynx. Arch Otolaryngol $28: 841 \sim 910,1938$.

2 ) Holinger PH and Johnston KC: Benign tumor of larynx. Ann Otol Rhinol Laryngol $51:$ 122 126, 1942.

3 ) 中島礼士, 坂本正邦, 内海重光: 喉頭神経線維腫症例. 日 耳鼻 $68: 809,1965$.

4 ) 河野 寿, 池松武之亮：喉頭 Neurofibroma の 1 例. 耳鼻 臨床 $64: 1246 \sim 1249,1971$

5 ) 高橋健一, 荒井英爾, 高橋 剛, 他 : 喉頭神経鞴腫症例. 日耳鼻 $75: 695,1972$.

6 ) 織田正道, 三橋重信, 平野 実, 他 : 声帯 Neurofibroma の 1 症例. 日耳鼻 $83: 769 \sim 774,1980$.

7 ）鈴木 徹, 代田正道, 武本欣也, 他: 喉頭神経線維腫の 1 例. 日気食会報 $32: 106,1981$.

8 ）佐藤修治, 夜陣紘治, 原田康夫, 他：喉頭の神経線維腫の 1 症例. 耳喉 $56: 129 \sim 134,1984$.

9 ) 角谷明子, 嶋田耿子, 鈴木晴彦, 他：喉頭蓋神経線維腫の
1 症例. 日耳鼻 $89: 1095,1986$.

10）福田郁夫, 大城和夫, 小笠原寛, 他 : 小児声門下神経線維 腫の一例. 耳鼻臨床 $79: 1916 \sim 1917,1986$.

11）田頭宣治, 山下隆司, 酒井利忠, 他：喉頭神経線維腫を伴 った von Recklinghausen 氏病の 1 例. 耳喉 $58: 581 〜 585$, 1986.

12）今村純一, 稲葉博司, 浅井正嗣, 他 : 喉頭披裂部に発生し た神経線維腫の 1 例. 日耳鼻 $91: 297,1990$.

13）関聡, 五十嵐文雄, 新島 元, 他: 喉頭に発生した神 経線維腫症の 1 例. 日耳鼻 $93: 1941,1990$.

14）小崎寛子, 岩村 忍, 栗田宣彦, 他 : 片側㗋頭を占拠した 巨大な喉頭神経線維腫の 1 例. 日気食会報 $42: 192,1991$.

15）久 育男, 立本圭吾, 出島健司, 他: 炭酸ガスレーザー手 術が有効であった喉頭神経線維腫の 1 例. 日耳鼻 97 : 1818 1819, 1994.

16）北嶋和智, 山内一浩, 澤田 泉: 喉頭の神経線維腫例. 耳 鼻臨床 $89: 1306 \sim 1307,1996$.

17）黒崎喜久, 海老原玲子, 倉本憲明 : 頭頸部神経原性腫瘍の 画像診断. 臨放 $38: 1091 \sim 1098,1993$.

18) Cumming CW, Montgomery $\mathrm{WW}$ and Balogh $\mathrm{K}$ : Neurogenic tumor of the larynx. Ann Otol Rhinol Laryngol 78 : 76 95, 1969.

$\left(\begin{array}{l}\text { 原稿受付: 平成 } 9 \text { 年 } 1 \text { 月 } 10 \text { 日 } \\ \text { 原稿採択 : 平成 } 9 \text { 年 } 2 \text { 月 } 26 \text { 日 } \\ \text { 別刷請求先 : 本島ひとみ } \\ \text { 干930-01 富山市杉谷 } 2630 \\ \text { 富山医科薬科大学耳鼻咽喉科学教室 }\end{array}\right)$

